\title{
Sürdürülebilir Kalkınma Amaçları Bağlamında Kurumsal Sosyal Sorumluluk Uygulamaları: Türkiye'de Mevcut Durum ve Eğilimler ${ }^{1}$
}

\author{
Muhammet Ali TILTAY*, Murat ÖZ**, Mustafa Enes TEPE***
}

öz

$\mathrm{Bu}$ çalışmada Türkiye Kurumsal Sosyal Sorumluluk Derneği (TKSSD), Türkiye İşveren Sendikaları Konfederasyonu (TISK), Sürdürülebilirlik Akademisi tarafından KSS faaliyetleri ödüllendirilen ve 2018-2020 dönemi BİST Sürdürülebilirlik Endeksi'nde yer alan işletmelerin internet sitelerinde yer alan KSS projeleri etik teoriler kapsamında yer alan sürdürülebilir kalkınma yaklaşımı bağlamında incelenmiştir. 126 işletme tarafından gerçekleştirilen $520 \mathrm{KSS}$ faaliyeti analiz edilmiştir. Çalışmada amaçlı örneklem tekniklerinden ölçüt örneklem kullanılmıştır. İşletmelerin internet sitelerinde yayımladıkları KSS projeleri nitel ve nicel içerik analizine tabi tutulmuştur. Analiz edilen KSS faaliyetleri pazarlama ve kurumsal sosyal girişimler (Kotler vd., 2012) ile Birleşmiş Milletler Sürdürülebilir Kalkınma Amaçları (SKA) indeksi bağlamında sınıflandırılmıştır. Çalışmanın sonuçlarına göre, pazarlama ve kurumsal sosyal girişimler bağlamında analiz edilen KSS projelerinin çoğunluğu (\%67) kurumsal odaklı girişimler kapsamındadır. Küresel amaçlar bağlamında ise her dört projeden üçü eşitsizliklerin azaltılması, nitelikli eğitim, karasal yaşam, sağlıklı ve kaliteli yaşam ve toplumsal cinsiyet eșitliği amaçlarına yöneliktir. Ayrıca, analiz edilen işletmelerin \%41'i imalat sektöründe yer alırken, \%65'inin menşei ülkesi Türkiye'dir.

\section{Anahtar Kelimeler: Kurumsal sosyal sorumluluk, Pazarlama ve kurumsal sosyal girişimler, Küresel JEL Sınıflandırması: M31 amaçlar, Sürdürülebilirlik, Sürdürülebilir kalkınma amaçları \\ Corporate Social Responsibility Practices in the Context of Sustainable Development Goals: Current Situation and Trends in Turkey}

\begin{abstract}
In this study, CSR projects of the businesses awarded by the Corporate Social Responsibility Association of Turkey (CSR Turkey), Turkish Confederation of Employer Association, Sustainability Academy and listed in the BIST Sustainability Index for the period of 2018-2020 were examined. The reports are analyzed in the context of the sustainable development approach which is within the ethical theories. 520 CSR activities carried out by 126 businesses were analyzed. Criterion sampling, one of the purposeful sampling techniques, was applied in the study. Qualitative and quantitative content analysis was performed of CSR projects reported by businesses on their websites. The CSR activities analyzed were classified in the context of marketing and corporate social initiatives (Kotler et al., 2012) and the United Nations Sustainable Development Goals (SDGs) index. The results indicate that the majority (67\%) of the CSR projects analyzed within the scope of marketing and corporate social initiatives are under the corporate-driven initiatives. In the context of the global goals, three of every four projects are for reduced inequalities, quality education, life on land, good health and well-being, and gender equality goals. In addition, $41 \%$ of the analyzed businesses are in the manufacturing sector, while Turkey is the country of origin of $65 \%$ of them.
\end{abstract}

Keywords: Corporate social responsibility, Marketing and corporate social initiatives, The global goals, Sustainability, The sustainable development goals

JEL Classification: M31

Geliș Tarihi / Received: 17.02.2021 Kabul Tarihi / Accepted: 16.04.2021 Doi: 10.17541/optimum. 897786

\footnotetext{
${ }^{1}$ Bu çalışma 1-4 Mayıs 2019 tarihlerinde 24. PPAD Pazarlama Kongresinde sunulan "Stratejik Bir Pazarlama Aracı Olarak Kurumsal Sosyal Sorumluluk Uygulamaları: Türkiye'de Mevcut Durum ve Eğilimler" başlıklı bildirinin genişletilmiş halidir.

* Doç. Dr., Eskişehir Osmangazi Üniversitesi, İ̈BF, İşletme Bölümü, matiltay@ogu.edu.tr, ORCID: 0000-0001-78778523

** Doç. Dr., Karamanoğlu Mehmetbey Üniversitesi, İİBF, İșletme Bölümü, muratoz@kmu.edu.tr, ORCID: 00000003-4955-3848

*** Arş. Gör., Karamanoğlu Mehmetbey Üniversitesi, İIBF, İşletme Bölümü, menestepe@kmu.edu.tr, ORCID: 00000002-9350-0754
} 


\section{GİRIŞ}

Birçok işletme için stratejik öneme sahip olan Kurumsal Sosyal Sorumluluk (KSS) işletmelerin, uzun vadede değer yaratma amaciyla çevresel, ekonomik, sosyal alanlarda tüm paydaşların çıkarlarının gözetilerek sürdürülebilir bir dünyaya gönüllü destekte bulunmasıdır. Ekonomik ve teknolojik gelişmeler neticesinde artan üretim hacimlerinin olumlu tarafları olduğu gibi tüm ekosistemi etkileyen olumsuz sonuçları da görülmektedir. Çevre kirliliği, doğal kaynakların tüketilmesi, küresel ısınma ve benzeri sorunlara ek olarak artan bilinçli tüketici popülasyonu firmaları salt karlılık odaklılıktan uzaklaşmaya itmiştir. Özellikle bireylerin sağlığı ve çevre üzerinde yoğun etkileri olan sektörler üzerindeki sorumluluk daha da artmıştır. Bununla beraber, üretilen mal ve hizmetlerle kar maksimizasyonunu hedefleyen işletmelerin varlığını devam ettirmesi geçmişe göre daha da zorlaşmıştır. İşletmeler, sadece ekonomik hedefler gözeten kurumlar olmanın ötesinde sürdürülebilirlik odaklı aktif özneler konumuna gelmiştir. İşletmelerin bu yeni konumu pazarlama kararları üzerinde de sonuçlar doğurmuştur. Özellikle, pazarlama iletişimi kapsamında KSS faaliyetlerinin duyurulması işletmelerin kurumsal imaj (örn: Kim vd., 2020) ve itibarı (örn: Esen, 2013) üzerinde doğrudan etkiye sahiptir. Bu durumun sonucunda artan kurum imajı ve itibarı tüketicilerin işletmelere yönelik olumlu çağrışımlarını artırırken işletmelerin finansal gelişimine de katkı sunmaktadır. Bu yönüyle işletmeler KSS faaliyetlerini stratejik bir pazarlama aracı olarak kullanmakta ve faaliyetlerini yazılı ve görsel olarak kamuoyuyla paylaşmaktadır. İşletmelerin KSS raporları işletmelerin farklı sosyal sorumluluk boyutlarındaki faaliyetlerinin bir göstergesi olmaktadır.

Sosyal sorumluluk faaliyetleri tüketicinin satın alma niyeti (Lee ve Shin, 2010), algis1 (Arli ve Lasmono, 2010), sadakati (Martínez ve Del Bosque, 2013) üzerinde etkilidir. Bunun yanında tüketiciler, işletmelerin sadece kar elde etme amaçlarından ziyade topluma yönelik sorumluluklarının olduğunu belirtmektedirler. İşletmelerin toplum içindeki rollerine ilişkin yapılan araştırmada katılımcıların sadece \%6'sı işletmelerin tek amacının kar elde etmek olduğunu, bunun yanında \%93'ü işletmelerin sorumlu bir şekilde faaliyetlerini sürdürme ve sosyal ve çevresel sorunları ele almada yasaların gerektirdiği asgari standartların ötesine geçmesi gerektiğini, \%94'ü ise işletmelerin iş uygulamalarının dünyayı nasıl etkilediğini analiz etmesi ve etkiyi olabildiğince olumlu hale getirmek için bu uygulamaları geliştirmesi gerektiğini ifade etmiştir (Cone Communications, 2011: 5). Ayrıca, işletmelerin kurumsal sosyal performansı ile finansal performansı arasındaki pozitif korelasyon (Van Beurden ve Gössling, 2008) işletmeleri sosyal sorumluluk faaliyetlerine daha çok önem vermeye itmiştir. Çok uluslu şirketlerin kurumsal hayırseverlik kapsamında yaptıkları katkıların ortalaması da artış göstermektedir (Lev vd., 2010: 182). Fortune 500 şirketlerinin \%90’1 kendi KSS girişimlerine sahipken, bu şirketlerin yarıdan fazlası yıllık KSS raporları hazırlamaktadır (Homburg vd., 2013: 54).

Literatürde işletmelerin KSS faaliyetlerine ilişkin raporlarının ele alındığı çalışmalar bulunmaktadır (Idowu ve Towler, 2004; Sert 2012; Suher 2010; Tate vd., 2010; Holcomb vd., 2007; Çetin vd., 2015; Altuntaş ve Türker, 2012). Bunun yanında, gelişen bir pazar olan Türkiye'de bulunan işletmelerin KSS uygulamalarının nasıl bir seyir izlediği yönündeki çalışmalar (Suher, 2010; Pusak, 2014; Soysal 2018, Demirel, 2018; Süklüm ve Hiçyorulmaz, 2019; Aytar, 2019; Macit, 2020) ise sınırlı sayıdadır. Ancak Türkiye'deki KSS uygulamalarının pazarlama ve kurumsal sosyal girişim (Kotler vd., 2012) bağlamında ele alan çalışmaya rastlanamamıştır. Sürdürülebilir Kalkınma Amaçları bağlamında ele alan çalışma (Maç vd., 2020; Mucan vd., 2016; Madran ve Tanyeri, 2020) ise hem çok sinırlı hem de kapsam olarak mevcut çalışmaya göre dardır. Bu sebeple, çalışmanın temel katkısı Türkiye'de faaliyette bulunan işletmelerin KSS uygulamalarının pazarlama ve kurumsal sosyal girişim (Kotler vd., 2012) ve sürdürülebilir küresel amaçlar bağlamında mevcut durum ve eğilimlerinin ortaya çıkarılmasıdır. Ayrıca, Türkiye'deki yerel ve yabancı menşeli işletmelerin KSS uygulamalarına benzer faaliyetlerde bulunup bulunmadıkları da belirlenmiş olacaktır. 
Bu çalışmanın amacı Türkiye'de faaliyette bulunan işletmelerin sürdürülebilir kalkınma amaçları ile pazarlama ve kurumsal sosyal girişimler bağlamında KSS uygulamalarına ilişkin mevcut durum ve eğilimlerin ortaya konmasıdır. Bu bağlamda Türkiye Kurumsal Sosyal Sorumluluk Derneği (TKSSD), Türkiye İşveren Sendikaları Konfederasyonu (TISK), Sürdürülebilirlik Akademisi tarafından KSS faaliyetleri ödüllendirilen ve Kasım 2018 - Ekim 2019 ile Kasım 2019 - Ekim 2020 dönemi BİST Sürdürülebilirlik Endeksi'nde yer alan işletmelerin internet sitelerinde yer alan KSS raporları incelenmiştir.

\section{KAVRAMSAL ÇERÇEVE}

Kurumsal sosyal sorumluluk kavramı ilk olarak H. Bowen tarafindan 1953 yılında yayımlanan "İşadamlarının Sosyal Sorumlulukları" isimli kitabında kullanılmıştır. Bowen, işadamlarının, toplumun değerleriyle uyumlu sosyal sorumluluk faaliyetleriyle ilgilenmeleri gerektiğini savunmuştur (Aktan ve Börü, 2007: 7). 1950'lerden sonra kurumsal sosyal duyarlılık, kurumsal sosyal tepkiler, kurumsal sosyal performans gibi kavramlar ile birlikte kavramsallaştırılan kurumsal sosyal sorumluluk temelde yönetim literatürüne konu olmuştur. Pazarlama akademisyenlerinin kurumsal sosyal sorumluluğa yönelik ilgisi ise 1960 ve 1970'lerde başlamıştır. O dönem araştırmacıların odak noktası işletmelerin genel sosyal rolünden ziyade, pazarlama işlevine bağl1 sosyal görevlerdir (Maignan ve Ferrell, 2004: 4). Bu dönemde Kotler ve Levy (1969) pazarlamanın salt satış faaliyetlerinin ötesine geçen ve her tarafa nüfuz eden toplumsal bir faaliyet olduğunu dile getirmiştir. Her ne kadar pazarlama kavramının belirli sınırlar içerisinde ele alınması gerektiğini savunanlar (örneğin: Luck, 1969) olsa da zaman içerinde sosyal pazarlama (Kotler ve Zaltman, 1971) alanının da ortaya çıkmasıyla beraber pazarlamanın toplumsal alana olan katkısı gelişim göstermiştir.

Geniş ve büyüyen bir araştırma kütlesine sahip olmasına rağmen, kurumsal sosyal sorumluluğun yaygın olarak kabul edilen bir tanımı bulunmamaktadır. Terimin anlamı ve temel unsurları hakkında ilk kullanıldığından bu yana tartışmalar bulunmaktadır (Jackson ve Apostolakou, 2010: 372). Okoye (2009) bu durumu kurumsal sosyal sorumluluk kavramının tartışmalı doğasından kaynaklandığını belirtmektedir. Bazı araştırmacılar kavramı bir firmanın müşteriler, tedarikçiler, düzenleyiciler, çalışanlar, yatırımcılar ve toplum gibi farklı paydaşlarına yönelik davranışının bir işlevi olarak değerlendirirken, diğer grup araştırmacılar firmanın sosyal, politik, çevresel, ekonomik ve etik eylemlerini içeren isteğe bağll çok boyutlu faaliyetleri olarak tanımlamaktadır (Malik, 2015: 423). Genel olarak benzer çerçeveye sahip bu tanımları inceleyen Dahlsrud (2008) beş boyuta ulaşmıştır. Bu boyutlar; çevre, sosyal, ekonomik, paydaş ve gönüllülük boyutlarıdır. Ahi ve Searcy (2013) işletme sürdürülebilirliği tanımlarını ele aldıkları çalışmalarında 7 odak noktası saptamışlardır. Bu odak noktaları; ekonomik, çevresel, sosyal, paydaş, gönüllülük, esneklik ve uzun dönem odakl11ıktır.

Carroll (1991) kurumsal sosyal sorumluluk piramidi adını verdiği boyutlandırmasında kurumsal sosyal sorumluluğu dört boyutta ele almaktadır. Bu boyutlar (40-41):

- Ekonomik sorumluluklar, hisse başına kazancı maksimize edecek şekilde tutarlı bir şekilde hareket etmenin; mümkün olduğunca karlı olmaya kararlı olmanın; güçlü bir rekabetçi konumu sürdürmenin; yüksek düzeyde çalışma verimliliği sağlamanın; başarılı bir firmanın sürekli olarak karlı olan bir firma olarak tanımlanmasının önemine vurgu yapmaktadır.

- Yasal sorumluluklar, hükümetin ve hukukun beklentileriyle tutarlı bir şekilde çalışmanın; bölgesel ve yerel düzenlemelere uymanın, yasalara saygılı bir kurumsal vatandaş olmanın, başarılı bir firmanın yasal yükümlülüklerini yerine getiren bir firma olarak tanımlanmasının, en azından asgari yasal gereksinimleri karşılayan mal ve hizmetlerin sağlanmasının önemine vurgu yapmaktadır. 
- Etik sorumluluklar, toplum gelenekleri ve etik normların beklentileri ile tutarlı bir şekilde faaliyette bulunmanın; toplum tarafından benimsenen yeni veya gelişen etik / ahlaki normları tanıma ve bunlara saygı duymanın; kurumsal hedeflere ulaşmak için etik normların tehlikeye atılmasını önlemenin; iyi bir kurumsal vatandaşlığın ahlaki veya etik açıdan bekleneni yapmak olarak tanımlanmasının; kurumsal dürüstlüğün ve etik davranışın sadece yasa ve yönetmeliklere uymanın ötesine geçtiğini tanımanın önemine vurgu yapmaktadır.

- Filantropik sorumluluklar, toplumun filantropik ve hayırseverlik beklentileriyle tutarlı bir şekilde hareket etmenin; güzel sanatlar ve sahne sanatlarına destek olmanın; yöneticilerin ve çalışanların kendi yerel topluluklarında gönüllü ve hayır amaçlı faaliyetlere katılmalarının; özel ve kamu eğitim kurumlarına destek olmanın; toplumun "yaşam kalitesini" artıran projelere gönüllü olarak destek olmanın önemine vurgu yapmaktadir.

\subsection{Sürdürülebilir Kalkınma Yaklaşımı}

Kurumsal sosyal sorumluluk alanı çeşitli teoriler bağlamında ele alınmaktadır. Gargiga ve Mele (2004) KSS ile ilgili teorileri dört ana başlıkta toplamaktadır. Bunlar; (1) enstrümantal teoriler, (2) politik teoriler, (3) bütünleştirici teoriler ve (4) etik teorilerdir. Enstrümantal teoriler, işletmelerin servet yaratmanın bir aracı olduğunu ve bu durumun işletmenin tek sosyal sorumluluğu olduğunu varsaymaktadır. $\mathrm{Bu}$ teoriler işletme ve toplum arasındaki etkileşimin sadece ekonomik yönünü dikkate almaktadır. Politik teoriler, işletmenin sosyal gücünün, özellikle toplumla olan ilişkisi ve bu güçle bağlantılı politik arenadaki sorumluluğunu vurgulamaktadır. Bütünleştirici teoriler, işlemenin sosyal talepleri entegre etmesi gerekliliğini dikkate almaktadır. Bu teoriler, genellikle işletmenin sürekliliği ve büyümesi için ve hatta işletmenin kendisinin varlığ için topluma bağlı olduğunu iddia ederler. Son olarak etik teoriler ise, işletme ve toplum arasındaki ilişkinin etik değerlerle iç içe olduğunu belirtmektedir. Etik teorilere göre bu durum, etik perspektiften bir KSS vizyonuna yol açar ve sonuç olarak, işletmeler sosyal sorumlulukları diğer tüm hususların üzerinde bir etik yükümlülük olarak kabul etmelidirler (Gargiga ve Mele, 2004: 52-53). Sürdürülebilir kalkınma yaklaşımı bu teorilerden etik teoriler kapsamında ele alınmaktadır.

Dünya Çevre ve Kalkınma Komisyonu (World Commission on Environment and Development, WCED) 1987 yılında "Ortak Geleceğimiz” başlıklı bir rapor yayımlamıştır. Bu rapor aynı zamanda Brundtland Raporu olarak da bilinmektedir. Bu raporda kendisine geniş yer bulan sürdürülebilir kalkınma kavramı "gelecek nesillerin kendi ihtiyaçlarını karşılama yeteneklerinden ödün vermeden günümüzün ihtiyaçlarını karşılama" olarak tanımlanmıştır (WCED, 1987: 43). Her ne kadar rapor sadece çevre odaklı olsa da 1990'lar boyunca, sürdürülebilir kalkınmanın kapsamı hem genişletilmiş hem de derinleştirilmiş̧ir. Sürdürülebilir kalkınma 2000'lerden sonra ise, kısa ve uzun vadede tüm toplumsal alan ve seviyelerde ekonomik, sosyal ve çevresel konuların entegrasyonunu talep eden iyi bilinen bir toplumsal rehberlik modeli olarak karşımıza çıkmaktadır (Steurer vd. 2005: 264).

Sürdürülebilir kalkınmanın genel olarak kabul edilen üç boyutu bulunmaktadır. $\mathrm{Bu}$ boyutlar (Harris, 2000: 25):

Ekonomik Boyut: Ekonomik olarak sürdürülebilir bir sistem, sürekli olarak mal ve hizmetler üretebilmeyi, yönetilebilir hükümet ve dış borç düzeylerini koruyabilmeyi ve tarımsal veya endüstriyel üretime zarar veren aşırı sektörel dengesizliklerden kaçınabilmeyi ifade etmektedir.

Çevresel Boyut: Çevresel açıdan sürdürülebilir bir sistem, istikrarlı bir kaynak temeli sağlamayı, yenilenebilir kaynak sistemlerinin veya çevresel yutak işlevlerinin aşırı kullanımından kaçınmayı ve yenilenemeyen kaynakları yalnızca yatırımın yetersiz ikame maddelere 
dönüştürüldüğ̈̈ ölçüde tüketilmesini ifade etmektedir. $\mathrm{Bu}$, biyolojik çeşitliliğin, atmosferik istikrarın ve normalde ekonomik kaynaklar olarak sinıflandırılmayan diğer ekosistem işlevlerinin korunmasını içermektedir.

Sosyal Boyut: Sosyal açıdan sürdürülebilir bir sistem, dağıtım eşitliğini, sağlık ve eğitim dahil sosyal hizmetlerin yeterli sunumu, cinsiyet eşitliğini ve siyasi hesap verebilirlik ve katılımı sağlamayı ifade etmektedir.

Brundtland Raporu 1992'deki Rio Dünya Zirvesi olarak bilinen Birleşmiş Milletler Çevre ve Kalkınma Konferansı'nı ortaya çıkarmıştır. Bu konferans sonucunda, sürdürülebilir kalkınmanın uluslararası toplumun gündeminde öncelikli bir madde haline gelmesi gerektiği ifade edilmiş ve sürdürülebilir kalkınmanın ekonomik, sosyal ve çevresel yönlerini ele almak için ulusal stratejilerin tasarlanmasını ve geliştirilmesini tavsiye edilmiştir. Daha sonrasında 2002 y1lında Johannesburg'da toplanan Rio+10 olarak da bilinen Dünya Sürdürülebilir Kalkınma Zirvesi düzenlenmiştir. Bu zirvede Rio Dünya Zirvesi sonuçlarının uygulanmasındaki ilerlemeler ele alınmıştır. Son olarak, 2012 yılında aşağıda da detaylandırdığımız Rio+20 veya Birleşmiş Milletler Sürdürülebilir Kalkınma Konferansı düzenlenmiştir. Bu konferans neticesinde sürdürülebilir kalkınma BM'nin eylem gündeminde beș temel öncelikten birisi olarak belirlenmiş ve sürdürülebilir kalkınmanın uluslararası ve ulusal kalkınma politika, program ve gündemlerinde oynaması gereken kilit rol vurgulanmıştır (Mensah, 2019: 7-8).

\subsection{Sürdürülebilir Kalkınma İçin Küresel Amaçlar}

Sürdürülebilir Kalkınma Hedefleri ilk olarak 2012 yılında Rio de Janeiro'da gerçekleştirilen Birleşmiş Milletler Sürdürülebilir Kalkınma Konferansı'nda ortaya çıkmıştır. Amacı, çevresel, siyasi ve ekonomik sorunları ele alan evrensel hedefler belirlemektir. Sürdürülebilir Kalkınma Hedefleri 2000 yılında başlatılan Binyıl Kalkınma Hedefleri'nin yerini almıştır. Bu doğrultuda Birleşmiş Milletler tarafından küresel sürdürülebilir kalkınma hedefleri belirlenmiştir. Küresel Sürdürülebilir Kalkınma Amaçları ${ }^{2}$, tüm insanlığın barış ve refah içerisinde yaşaması, yoksulluğun yok edilmesi, gezegenin korunması için Ocak 2016 yılında yürürlüğe giren, 170'ten fazla ülke ve bölgede çalışma yürüten, 2030 yılına kadar UNDP (United Nations Development Programme-Birleşmiş Milletler Kalkınma Programı) politikası ve finansmanına rehberlik edecek evrensel eylem çağrısıdır. Bu belirlenen amaçlar sayesinde ortak yönleri olan sorunların daha katılımcı ve etkili bir şekilde çözülmesi amaçlanmaktadır. Bu çerçevede sürdürülebilir kalkınma için 17 amaç, bu amaçlara erişmek için 169 hedef belirlenmiştir (tr.undp.org).

\footnotetext{
2 2015'te Türkiye dahil Birleşmiş Milletlere üye 193 ülke tarafindan belirlenen Sürdürülebilir Kalkınma Hedefleri, diğer adıyla Küresel Hedeflerin 15 Temmuz 2019 tarihinden itibaren Sürdürülebilir Kalkınma Amaçları (Küresel Amaçlar) olarak adlandırılmasına karar verilmiştir.
} 
Tablo 1: Sürdürülebilir Kalkınma Amaçları ve Hedefleri

\begin{tabular}{ll}
\hline \multicolumn{1}{c}{ Sürdürülebilir Kalkınma Amaçları } & \multicolumn{1}{c}{ Sürdürülebilir Kalkınma Hedefleri } \\
\hline 1. Yoksulluğa Son & $\begin{array}{l}2030 \text { yllına kadar yoksulluğun tüm şekilleriyle sona } \\
\text { erdirilmesi. }\end{array}$ \\
\hline 2. Açlığa Son & $\begin{array}{l}\text { Açlı̆̆ın sonlandırılması, gıda güvenliğinin sağlanması, } \\
\text { beslenmenin geliştirilmesi ve sürdürülebilir tarımın } \\
\text { teşvik edilmesi. }\end{array}$ \\
\hline 3. Sağlıklı ve Kaliteli Yaşam & $\begin{array}{l}\text { Sağlıklı yaşamları güvence altına alınması ve } \\
\text { mutluğun her yaşta desteklenmesi. }\end{array}$ \\
\hline 4. Nitelikli Eğitim & $\begin{array}{l}\text { Herkes için kapsayıcı ve nitelikli eğitimin sağlanması } \\
\text { ve yaşam boyu öğrenimin desteklenmesi. }\end{array}$ \\
\hline 5. Toplumsal Cinsiyet Eşitliğgi & $\begin{array}{l}\text { Toplumsal cinsiyet eşitliğinin sağlanması ve kadınların } \\
\text { ve kız çocuklarının konumlarının güçlendirilmesi. }\end{array}$
\end{tabular}

6. Temiz Su ve Sanitasyon

7. Erişilebilir ve Temiz Enerji

8. İnsana Yakışır İş ve Ekonomik Büyüme

9. Sanayi, Yenilikçilik ve Altyapı

10. Eşitsizliklerin Azaltılması

11. Sürdürülebilir Şehirler ve Topluluklar

12. Sorumlu Üretim ve Tüketim

13. İklim Eylemi

14. Sudaki Yaşam

15. Karasal Yașam

16. Barış, Adalet ve Güçlü Kurumlar

17. Amaçlar İçin Ortaklıklar

Kaynak: https://www.kureselamaclar.org/

${ }^{3}$ Ana hedefler verilmiştir.
Herkes için suyun ve sıhhi koşulların erișilebilirliği ve sürdürülebilir yönetiminin güvence altına alınması.

Herkesin uygun fiyatlı, güvenilir, sürdürülebilir ve modern enerjiye erişiminin güvence altına alınması.

Kesintisiz, kapsayıcı ve sürdürülebilir ekonomik büyümenin, tam ve üretken istihdamın ve herkes için insana yakışır işlerin desteklenmesi.

Dayanıklı altyapıların inşası, kapsayıcı ve sürdürülebilir sanayileşmenin desteklenmesi ve yenilikçiliğin güçlendirilmesi.

Ülkeler içinde ve arasında eşitsizliklerin azaltılması.

Şehirlerin ve insan yerleşimlerinin kapsayıcı, güvenli, dayanıklı ve sürdürülebilir kılınması

Sürdürülebilir tüketim ve üretim kalıplarının güvence altına alınması.

İklim değişikliği ve etkileri ile mücadele konusunda acilen eyleme geçilmesi.

Sürdürülebilir kalkınma için okyanuslar, denizler ve deniz kaynaklarının korunması ve sürdürülebilir kullanımı.

Ormanların sürdürülebilir kullanımı, çölleşme ile mücadele, karasal bozulmanın durdurulması ve iyileştirilmesi ve biyoçeşitlilik kaybının engellenmesi.

Sürdürülebilir kalkınma için barışçıl ve kapsayıcı toplumların desteklenmesi, herkes için adalete erişimin sağlanması ve her düzeyde etkili, hesap verebilir ve kapsayıcı kurumların inşası.

Uygulama araçlarının güçlendirilmesi ve Sürdürülebilir Kalkınma için Küresel Ortaklığın canlandırılması. 


\subsection{Pazarlama ve Kurumsal Sosyal Girişimler}

İşletmeler, KSS faaliyetleri kapsamında çeşitli girişimlerde bulunmaktadır. Bu girişimleri temelde iki başlık altında toplamak mümkündür: (1) Pazarlama odaklı girişimler, (2) Kurumsal odaklı girişimler. "Bir kurumun toplum yararına yönelik faaliyetleri desteklemek, işletmesini güçlendirmek ve kurumsal sosyal sorumluluk taahhütlerini yerine getirmek için üstlendiği başlıca faaliyetler" (Kotler vd., 2012: 6) olarak tanımlanan pazarlama ve kurumsal sosyal girişimler kendi içinde üçer başlıkta ele alınmaktadır (Kotler vd., 2012).

\subsection{Pazarlama Odaklı Girişimler}

Esas olarak işletmelerin pazarlama fonksiyonu tarafından geliştirilen ve yönetilen girişimlerdir. Bu girişimler kurumsal sosyal pazarlama, sosyal amaçlı teşvikler ve amaca yönelik pazarlamadır.

Kurumsal Sosyal Pazarlama (Corporate Social Marketing): Odak noktas1 ve hedeflenen çıktısı halk sağlığı, güvenlik, çevre ve toplumsal refahın gelişmesi için davranış değişikliği meydana getirmektir. Başarılı bir kurumsal sosyal pazarlama faaliyeti durum analizi yapmayı, hedef kitleyi seçmeyi, davranış hedeflerini belirlemeyi, davranış değişikliğinin önündeki engelleri ve faydalarını belirlemeyi ve sonrasında algılanan engellerin üstesinden gelmeye yardımc1 olacak ve potansiyel faydaları maksimize edecek pazarlama karması stratejileri geliştirmeyi içeren stratejik pazarlama planlaması yaklaşımını kullanır (Kotler vd., 2012: 111). Kurumsal sosyal pazarlama kampanyaları, genellikle aşağıda belirtilen konulardaki davranış değişikliklerini desteklemeye odaklanmaktadır (Kotler vd., 2012: 112):

- Kanser, sigara kullanımının önlenmesi, yeme bozukluğu, kalp hastalıkları, AIDS ve ağız sağlığını kapsayan sağlıkla ilgili konular,

- Trafik güvenliği, boğulmanın önlenmesi, intihar ve acil durum hazırlığını kapsayan yaralanmayı önleyici konular,

- Su ve enerji tasarrufu, tarım ilaçları kullanımı, hava kirliliği, vahşi yaşam habitatları, çöp önlemeyi kapsayan çevreyle ilgili konular,

- Gönüllülük, oy verme, hayvan hakları, organ ve kan bağışı, suç önlemeyi kapsayan toplumun katılımıla ilgili konular.

Sosyal Amaçlı Teşvikler (Cause Promotion): Toplumsal bir soruna yönelik farkındalık ve ilgi artırmak veya bir soruna yönelik bağış toplamayı, katılımı veya gönüllü işe alımı desteklemek için kurumsal fonları, ayni katkıları veya diğer kaynakları kullanan sosyal amaçlı teşvik faaliyetleri genellikle aşağıdaki iletişim hedeflerine odaklanmaktadır (Kotler vd., 2012: 49-50):

- Motive edici istatistikler ve gerçekler sunarak bir sorun hakkında farkındalık ve ilgi oluşturmak. Örneğin, gece aç olarak yatmak zorunda olan çocuklara ilişkin sayısal verilerin duyurulmas1,

- İnsanları sorun hakkında daha fazla bilgi edinmeye ikna etmek. Örneğin, bir sokak köpeğinin sahiplenmesi hakkında bilgi elde etmek için ilgili internet sayfalarının nasıl ziyaret edileceğinin öğrenilmesi,

- İnsanları zamanlarını bağışlamaya ikna etmek. Örneğin, lösemiye yönelik farkındalık oluşturma amacıyla düzenlenen bir etkinliğe gönüllü katılım sağlama,

- İnsanları para bağışı yapmaya ikna etmek. Örneğin, şirketin internet sitesinde ziyaretçilere dezavantajlı çocukların eğitimi için nasıl bağış yapacaklarının gösterilmesi,

- İnsanları parasal olmayan kaynakları bağışlamaya ikna etmek. Örneğin, kullanılmayan ikinci el kıyafetlerin bağışlanması,

- İnsanları katılım sağlamaya ikna etmek. Örneğin, bağış toplamak için düzenlenen bir etkinliğe katılma. 
Amaca Yönelik Pazarlama (Cause-Related Marketing): Kar amacı gütmeyen belirlenmiş bir çaba için müşterilerin gelir sağlayan değişimlere katılımlarını sağlayan pazarlama faaliyetlerini formüle etme ve uygulama süreci olarak tanımlanmaktadır (Brønn ve Vrioni, 2001: 214). Tipik amaca yönelik pazarlama faaliyetleri şirketin teşvik edeceği bir veya daha fazla ürün, desteklenecek bir amaç ve bu faaliyetten faydalanacak bir veya daha fazla hayır kurumu veya kurumsal yapıyı kapsamalıdır. Bununla birlikte şeffaflık bakımından genel kabul görmüş uygulamalar şu şekilde sıralanmaktadır (Kotler vd., 2012: 83-84):

- Satılan her ürün için belirli bir para miktarı belirleme,

- Bir satış işleminin bir yüzdesinin hayır kurumuna taahhüt edilmesi,

- Bir tüketicinin satın alma eylemine karşılık olarak belirli bir ayni bağışta bulunulması,

- Somut bir hayırseverlik yararını garanti eden nakdi bir katkıda bulunma.

\subsubsection{Kurumsal Odaklı Girișimler}

Toplum ilişkileri, insan kaynakları, kurumlar ve operasyonlar dahil olmak üzere diğer kurumsal fonksiyonlar tarafından geliştirilen ve yönetilen girişimlerdir. Bunlar ise kurumsal hayırseverlik, işgücü gönüllülüğü ve sosyal sorumluluk esaslı iş uygulamalarıdır.

Kurumsal Hayırseverlik (Corporate Philanthropy): Kurumsal hayırseverlik, teorik olarak 1970'lerde şirketlerin yalnızca tüketicilere değil, aynı zamanda toplumun refahına da hizmet etmesi gerektiğini ifade eden toplumsal pazarlama kavramının ortaya çıkmasıyla başlamıştır (Gautier ve Pache, 2015: 348). Günümüze gelindiğinde kurumsal hayırseverlik uygulamaları esas olarak stratejik hayırsever katkılar olarak ifade edilmektedir. Şirketler verdiklerinin karşılığını geri almayı umarak, yaptıkları bağışların hem topluma hem de işletmeye aynı anda fayda getirmesi durumunda bağış yapmaktadır (Von Schnurbein vd., 2016: 281). Kurumsal hayırseverliğin özünde bir şirketin bir hayır kurumuna veya toplumsal bir amaca çoğunlukla nakit hibeler, bağışlar ve / veya ayni hizmetler şeklinde doğrudan katkıda bulunması vardır. Hayırseverlik çabaları genellikle şirket için öncelikli bir alanı yansıtan bir amaç seçmeyi, yapılacak katkının türünü belirlemeyi ve katkılar için bir alıcı belirlemeyi içermektedir. Bağış seçenekleri şu şekildedir (Kotler vd., 2012: 141-143):

- Nakit bağışta bulunmak. Örneğin, depremzedelere yönelik oluşturulan acil yardım fonuna nakdi yardımda bulunma,

- Hibede bulunmak. Örneğin, dezavantajlı bölgelerdeki okulların kütüphane oluşturma maliyetini üstlenme,

- Burs vermek. Örneğin, ekonomik olarak dezavantajlı öğrencilere daha kaliteli eğitim almaları için burs sağlama,

- Ürün bağışlamak. Örneğin, savaş mağdurlarına temel yaşam malzemeleri bağışlama,

- Hizmet bağışlamak. Örneğin, yaşlı bakımevi meskunlarına ağız ve diş bakımı sağlama,

- Teknik destek sağlamak. Örneğin, meslek lisesi öğrencilerine yönelik atölye çalışmaları organize etme,

- Tesislerin ve dağıtım kanallarının kullanımına izin vermek. Örneğin, marketlerin aşevlerine gönderilmek üzere konserve ürünlerin toplanması için alan ayırması,

- Ekipman kullanımı sağlamak. Örneğin, bilimsel bir etkinliğe öğrencilerin nakillerinin sağlanması için taşıma aracı sağlama.

İsgücü Gönüllülüğü (Workforce Volunteering): Gönüllülük, kâr amac1 gütmeyen örgütler, bağış grupları gibi gönüllü bir grup veya bir organizasyon için planlanan bir etkinlikte zamanın veya becerilerin vakfedilmesidir. Bu tanım üç bileşen barındırmaktadır. Birincisi, daha pasif bir yol olan parasal bağışlardan ziyade aktif olarak zaman ve becerilerin verilmesidir.

\footnotetext{
${ }^{4}$ İşyeri olarak da kullanılmaktadır.
} 
İkincisi, spontane (reaktif) yardım etme eyleminin aksine planlı (proaktif) bir faaliyettir. Sonuncusu ise, gönüllülük veya hayır kurumu bağlamında meydana gelmektedir (Rodell, 2013: 1274). Çalışanların gönüllü olduğu projeler aşağıda belirtilen şekillerde görülmektedir (Kotler vd, 2012: 160):

- Toplum projeleri. En yaygın olarak görülen proje türüdür. Bu projelere evler inşa etme, aşevleri için gıda toplama, yürüyüş etkinlikleri için ekipler organize etme, parkları temizleme, çocuklara kitap okuma, risk altındaki gençlere rehberlik etme, sınıflarda gönüllü olma, hastanelerde çocukları ziyaret etme, yaşlılarla bakımevlerinde zaman geçirme, evsizler barınağındaki insanlarla arkadaş olma, aşevinde yemek dağıtma, yetimler için oyun evleri inşa etme örnekleri verilebilir.

- Sağlık ve güvenlikle ilgili projeler. Çocukların diş problemlerinin tarama, gençlerin fiziksel aktivite programlarına liderlik etme, HIV ile ilgili eğitim broşürleri dağıtma gibi çalışanların zamanlarını harcadıkları projelerdir.

- Çevresel gönüllülük projeleri. Bu projeler kapsamında çalışanlar çöp toplama, yangın sonucu yok olmuş alanlarda fidan dikimi, somon habitatının korunması, zararlı ot kontrolü, sulak alan rehabilitasyonu, kirli suyollarının temizlenmesi gibi aktivitelere katılım sağlamaktadır.

Sosyal Sorumluluk Esaslı İş Uygulamaları (Socially Responsible Business Practices): Toplumun iyiliğini hedefleyen uygulamaları desteklemek, toplumun refahını iyileştirmek ve / veya çevreyi korumak için benimsenen ve yürütülen isteğe bağlı iş uygulamalarını ifade etmektedir (Kotler vd., 2012: 177). Genel olarak başvurulan sosyal sorumlu iş uygulamaları şu şekildedir (Kotler vd., 2012: 179-180):

- Çevre ve güvenlik önerilerini ve yönergelerini karşılayacak veya daha iyi olacak şekilde tesisler tasarlama,

- Süreç iyileştirmeleri geliştirme,

- Zararlı kabul edilen ancak yasa dışı olmayan ürün sunumlarının durdurma,

- Tedarikçileri, sürdürülebilir çevre uygulamalarını benimseme veya sürdürme istekliliklerine göre seçme, çabalarını destekleme ve ödüllendirme,

- Atık azaltma, yenilenebilir kaynakların kullanımı ve zehirli emisyonların ortadan kaldırılması hedeflerini dikkate alarak çevreye en duyarlı üretim ve ambalaj malzemelerini seçme,

- Ürün malzemelerinin, kökenlerinin ve potansiyel tehlikelerinin tam olarak açılanmasını sağlama,

- İşyeri egzersiz tesisleri gibi çalışanların refahını desteklemek için programlar geliştirme

- Hesap verilebilir hedef ve eylemlerin ölçülmesi, takibi ve raporlanmas1,

- Sorumlu iletişim ve uygun dağıtım kanalları sağlamak için çocuklara yönelik pazarlama yönergelerinin oluşturulması,

- Teknolojiyi kullanarak engelliler için daha fazla erişim sağlama,

- Tüketici bilgilerinin gizliliğini korumak,

- Tesis, dış kaynak kullanımı ve perakende satış yerleri ile ilgili kararlar alma ve bu kararların toplum üzerindeki ekonomik etkisinin önemini anlama.

\section{YÖNTEM}

$\mathrm{Bu}$ çalışma uygulamalı ve keşifsel bir araştırmadır. Veri toplama sürecinde doküman incelemeden faydalanılmıştır. Türkiye'de faaliyet gösteren işletmelerin web sayfalarında yayımladıkları KSS projeleri incelenmiştir.

Araştırmada amaçlı örneklem tekniklerinden ölçüt örneklem kullanılmıştır. KSS raporları incelenen işletmelerin seçiminde aşağıdaki ölçütler kullanılmıştır. 
- Türkiye Kurumsal Sosyal Sorumluluk Derneği'nden 2009-2019 yılları arasında kurumsal sosyal sorumluluk ödülü kazanan 57 işletme,

- Türkiye İşveren Sendikaları Konfederasyonu tarafından 2014-2018 yılları arasında ödül kazanan 32 işletme,

- Sürdürülebilirlik Akademisi tarafından 2014-2019 yılları arasında verilen Sürdürülebilir İş Ödülleri'ni alan 45 işletme,

- Kasim 2018 - Ekim 2019 ile Kasım 2019 - Ekim 2020 dönemi BİST Sürdürülebilirlik Endeksi'nden 47 işletmenin web sayfalarında yer alan sosyal sorumluluk raporları incelenmiştir.

Araştırmada sosyal sorumluluk raporları incelenen işletmelerden 32 tanesi yukarıda yer alan ölçütlerden iki grupta, 6 tanesi üç grupta, 3 tanesi de 4 grupta da yer almaktadır. Bu açıdan belirtilen toplam sayılar tekrarlardan arındırılmıştır. Araştırmada toplam 126 işletmenin yürüttüğ̈ 520 sosyal sorumluluk projesi analiz edilmiştir.

Bu çalışmada nitel ve nicel içerik analizi kullanılmıştır (Krippendorf, 2004; Hsieh ve Shannon, 2005). Araştırma kapsamında incelenen faaliyet raporları her bir araştırmacı tarafından içerik analizine tabi tutulmuştur. Çalışmada önceden belirlenmiş konu başlıkları altında bir sınıflandırma yapılmışır. Bu sınıflandırmalarda araştırmacılar tarafından ikili bir sınıflandırma yaklaşımı benimsenmiştir. Bunlar;

- Pazarlama ve kurumsal sosyal girişimler (Kotler vd., 2012)

- Birleşmiş Milletler sürdürülebilir kalkınma amaçları indeksi

$\mathrm{Bu}$ çalışma, kapsamı gereği etik kurul onayı gerektirmemektedir.

\section{BULGULAR}

Tablo 2: Pazarlama ve Kurumsal Sosyal Girişimlere Göre KSS Faaliyetleri

\begin{tabular}{|c|c|c|c|c|c|c|c|c|}
\hline & & \multicolumn{3}{|c|}{ Pazarlama Odaklı Girişimler } & \multicolumn{3}{|c|}{ Kurumsal Odaklı Girişimler } & \multirow[b]{2}{*}{$\begin{array}{l}\text { Top } \\
\text { lam }\end{array}$} \\
\hline & $\begin{array}{l}\text { Firma } \\
\text { Sayısı }\end{array}$ & $\begin{array}{c}\text { Kurumsal } \\
\text { Sosyal } \\
\text { Pazarlama }\end{array}$ & $\begin{array}{c}\text { Sosyal } \\
\text { Amaçlı } \\
\text { Teşvikler }\end{array}$ & $\begin{array}{c}\text { Amaca } \\
\text { Yönelik } \\
\text { Pazarlama }\end{array}$ & $\begin{array}{c}\text { Kurumsal } \\
\text { Hayırseverlik }\end{array}$ & $\begin{array}{c}\text { İşyeri } \\
\text { Gönüll } \\
\text { üğüu }\end{array}$ & $\begin{array}{l}\text { KSS Esaslı İş } \\
\text { Uygulamaları }\end{array}$ & \\
\hline $\begin{array}{l}\text { TİSK (2014- } \\
\text { 2018) }\end{array}$ & 32 & 20 & 30 & 3 & 50 & 21 & 12 & 136 \\
\hline $\begin{array}{l}\text { BİST } \\
\text { Sürdürülebil } \\
\text { irlik Endeksi } \\
(\mathbf{2 0 1 8 - 2 0 2 0})\end{array}$ & 47 & 43 & 49 & 10 & 144 & 43 & 15 & 304 \\
\hline Toplam ${ }^{6}$ & 126 & 100 & 98 & 18 & 276 & 117 & 37 & 520 \\
\hline
\end{tabular}

Pazarlama ve kurumsal sosyal girişimler bağlamında analiz edilen 520 KSS projesinin yaklaşık \%70'i kurumsal odaklı girişimler, \%30'u ise pazarlama odaklı girişimler kapsamındadır. Analiz edilen projelerin büyük çoğunluğu birden fazla girişim kapsamına girmektedir. $\mathrm{Bu}$ duruma kan verme projesine şirketin çalışanlarıyla destek vermesi veya ekonomik dezavantajlı gruplara ilişkin farkındalık oluşturmayı amaçlayan projelere şirketin nakdi bağışta bulunması örnek olarak gösterilebilir. Pazarlama odaklı projelerde sosyal amaçlı teşvikler ile kurumsal sosyal pazarlama ön plana çıkmaktadır. Kurumsal sosyal pazarlama

\footnotetext{
52010 ve 2013 yılları dahil değildir.

6 Tekrar sayımdan arındırılmıştır.
} 
kapsamında kan ve kök hücre bağışı kampanyalarına, bireylere spor yapma alışkanlığının kazandırılmasına, trafik kazalarının önlenmesine, daha bilinçli tüketime özendirmeye yönelik faaliyetler yer almaktadır. Bunun yanında sosyal amaçlı teşviklerde ise toplumsal cinsiyet eşitliği, dezavantajlı grupların eğitim hakkı, engelli bireylerin yaşadıkları sorunlar ve çevresel problemler hakkında farkındalık oluşturmaya yönelik faaliyetler dikkat çekmektedir.

Kurumsal odaklı projelerde kurumsal hayırseverlik kapsamına giren projelerin daha yoğun olduğu görülmektedir. Kurumsal hayırseverlik kapsamında öğrenci bursları, fidan bağışları, afetzedelere ayni yardımlar, hastanelere ve okullara ekipman hibeleri gibi faaliyetler yer almaktadır. KSS projelerine şirketlerin çalışanları da katılım göstermektedir. İşyeri gönüllüğü kapsamında değerlendirilen bu faaliyetlere teknik destek, kan bağışı, fiziksel katılım gerektiren etkinlikler örnek verilebilir. Genel olarak belirtmek gerekirse, analiz edilen sosyal sorumluluk projeleri yoğunluk sırasına göre kurumsal hayırseverlik (\%43), işgücü gönüllülügü (\%18), sosyal amaçlı teşvikler (\%15), kurumsal sosyal pazarlama (\%15), KSS esaslı iş uygulamaları (\%6) ve amaca yönelik pazarlama (\%3) şeklinde dağglım göstermektedir.

Tablo 3: BM Sürdürülebilir Kalkınma Amaçlarına Göre KSS Faaliyetleri

\begin{tabular}{|c|c|c|c|c|c|c|c|c|c|c|c|c|c|c|c|c|c|c|c|}
\hline & $\begin{array}{c}\text { İşletme } \\
\text { Sayısı }\end{array}$ & 1 & 2 & 3 & 4 & 5 & 6 & 7 & 8 & 9 & 10 & 11 & 12 & 13 & 14 & 15 & 16 & 17 & Toplam \\
\hline $\begin{array}{l}\text { TKSSD } \\
\text { 2019) }\end{array}$ & 57 & 8 & 4 & 33 & 43 & 26 & 1 & 2 & 9 & 6 & 84 & 13 & 14 & 5 & 3 & 29 & 0 & 5 & 285 \\
\hline $\begin{array}{l}\text { TÍSK } \\
\text { 2018) }\end{array}$ & 32 & 2 & 1 & 9 & 21 & 17 & 0 & 0 & 11 & 2 & 24 & 9 & 3 & 2 & 1 & 11 & 0 & 2 & 115 \\
\hline SİÖ (2014-2019) & 45 & 4 & 8 & 21 & 38 & 21 & 0 & 5 & 7 & 2 & 52 & 4 & 14 & 4 & 0 & 18 & 0 & 3 & 201 \\
\hline $\begin{array}{l}\text { BİST } \\
\text { Sürdürülebilirlik } \\
\text { Endeksi } \\
\text { 2020) }\end{array}$ & 47 & 5 & 5 & 17 & 55 & 26 & 0 & 1 & 8 & 1 & 83 & 19 & 14 & 5 & 1 & 25 & 0 & 2 & 267 \\
\hline Toplam $^{7}$ & 126 & 12 & 11 & 53 & 105 & 51 & 1 & 7 & 21 & 8 & 159 & 32 & 30 & 11 & 4 & 60 & $\mathbf{0}$ & 6 & 518 \\
\hline
\end{tabular}

1.Yoksulluğa Son, 2. Açlığa Son, 3. Sağlıklı ve Kaliteli Yaşam, 4. Nitelikli Eğitim, 5. Toplumsal Cinsiyet Eşitliği, 6. Temiz Su ve Sanitasyon, 7. Erişilebilir ve Temiz Enerji, 8. İnsana Yakışır İş ve Ekonomik Büyüme, 9. Sanayi, Yenilikçilik ve Altyapı, 10. Eşitsizliklerin Azaltılması, 11. Sürdürülebilir Şehirler ve Topluluklar, 12. Sorumlu Üretim ve Tüketim, 13. İklim Eylemi, 14. Sudaki Yaşam, 15. Karasal Yaşam, 16. Barış Adalet ve Güçlü Kurumlar, 17. Amaçlar İçin Ortaklıklar

İşletmelerin sosyal sorumluluk projelerinin Sürdürülebilir Kalkınma Amaçlarına göre dağılımı incelendiğinde yoğunlaşmanın eşitsizliklerin azaltılması (\%28), nitelikli eğitim (\%18), karasal yaşam (\%11), sağlıklı ve kaliteli yaşam (\%10) ve toplumsal cinsiyet eşitliği (\%9) odaklı projelerde olduğu görülmektedir. Eşitsizliklerin azaltılması amacına yönelik faaliyetlere ekonomik dezavantajlı grupların gelişimini, engelli bireylerin güçlenmesini destekleyen projeler örnek olarak verilebilir. Meslek liselerinin, eğitime erişim imkanının yetersiz olduğu bölgelerin, cinsiyete bağlı meydana gelen eşitsizliklerin ortadan kaldırılmasının ve fiziksel imkanların geliştirilmesinin desteklenmesi nitelikli eğitim amacına hizmet etmektedir. Karasal yaşamı destekleyen faaliyetlerde özellikle ormanların, çevrenin ve biyoçeşitliliğin korunması faaliyetleri ön plana çıkmaktadır. Sağlıklı ve kaliteli yaşam amacı ise bağımlılıkla mücadele, trafik kazalarına bağlı gelişen olumsuzlukları önleme, gezici sağlık hizmetleri sunma gibi sağlıklı yaşamı geliştirmeye yönelik faaliyetlerle desteklenmektedir. İşletmelerin yoğunlaştığ amaç ise toplumsal cinsiyet eşitliğidir. Bu amaç kapsamında kadın istihdamını artırmaya ve kız çocuklarının eğitim imkanına kavuşmasına yönelik faaliyetler ön plana çıkmaktadır. Analiz edilen her dört projeden üçü yukarıda bahsedilen beş amaç kapsamında gerçekleştirilmiştir. Diğer amaçlara yönelik projelerin dağılımı sürdürülebilir şehir ve topluluklar (\%5), sorumlu tüketim ve üretim (\%5), insana yakışır iş ve ekonomik büyüme (\%4), açlığa son (\%2),

\footnotetext{
7 Tekrar sayımdan arındırılmıştır.
} 
yoksulluğa son (\%2), iklim eylemi (\%2), sanayi, yenilikçilik ve altyapı (\%1), erişilebilir ve temiz enerji $(\% 1)$ ve diğerleri $(\% 2)$ şeklindedir. Bu çalışma bağlamında incelenen sosyal sorumluluk raporlarında, birinci hedefi barış, adalet ve güçlü kurumlar olan sosyal sorumluluk projesi belirlenememiştir.

Tablo 4: Pazarlama ve Kurumsal Sosyal Girişimlere Göre KSS Faaliyetleri (Sektörel ${ }^{8}$ )

\begin{tabular}{|c|c|c|c|c|c|c|c|}
\hline \multirow[b]{2}{*}{$\begin{array}{l}\text { Sektör } \\
\text { Kodu }\end{array}$} & \multirow[b]{2}{*}{$\begin{array}{l}\text { İşletme } \\
\text { Sayısı }\end{array}$} & \multicolumn{3}{|c|}{ Pazarlama Odaklı Girişimler } & \multicolumn{3}{|c|}{ Kurumsal Odaklı Girişimler } \\
\hline & & $\begin{array}{c}\text { Kurumsal } \\
\text { Sosyal } \\
\text { Pazarlama }\end{array}$ & $\begin{array}{c}\text { Sosyal } \\
\text { Amaçlı } \\
\text { Teşvikler }\end{array}$ & $\begin{array}{c}\text { Amaca } \\
\text { Yönelik } \\
\text { Pazarlama }\end{array}$ & $\begin{array}{c}\text { Kurumsal } \\
\text { Hayırseverlik }\end{array}$ & $\begin{array}{c}\text { İşyeri } \\
\text { Gönüllüğü }\end{array}$ & $\begin{array}{l}\text { KSS Esaslı İş } \\
\text { Uygulamaları }\end{array}$ \\
\hline $\mathbf{J}$ & 12 & 13 & 10 & 0 & 28 & 9 & 5 \\
\hline $\mathbf{P}$ & 1 & 1 & 5 & 0 & 5 & 4 & 0 \\
\hline D & 13 & 10 & 9 & 3 & 21 & 7 & 3 \\
\hline K & 15 & 12 & 11 & 6 & 54 & 22 & 4 \\
\hline $\mathbf{N}$ & 1 & 0 & 1 & 0 & 0 & 0 & 0 \\
\hline $\mathbf{C}$ & 52 & 43 & 45 & 2 & 105 & 46 & 15 \\
\hline $\mathbf{F}$ & 5 & 4 & 1 & 0 & 10 & 2 & 4 \\
\hline $\mathbf{R}$ & 1 & 0 & 0 & 0 & 4 & 0 & 0 \\
\hline $\mathbf{M}$ & 4 & 0 & 2 & 1 & 1 & 2 & 0 \\
\hline $\mathbf{E}$ & 1 & 0 & 0 & 1 & 1 & 1 & 0 \\
\hline $\mathbf{G}$ & 11 & 11 & 6 & 5 & 20 & 16 & 5 \\
\hline $\mathbf{H}$ & 10 & 6 & 8 & 0 & 28 & 8 & 1 \\
\hline
\end{tabular}

J. Bilgi ve İletişim, P. Eğitim, D. Elektrik, Gaz, Buhar ve İklimlendirme Üretimi ve Dağıtımı, K. Finans ve Sigorta Faaliyetleri, N. İdari ve Destek Hizmet Faaliyetleri, C. İmalat, F. İnşaat, R. Kültür, Sanat, Eğlence, Dinlence ve Spor, M. Mesleki, Bilimsel ve Teknik Faaliyetler, E. Su Temini; Kanalizasyon, Atık Yönetimi ve İyileştirme Faaliyetleri, G. Toptan ve Perakende Ticaret; Motorlu Kara Taşıtlarının ve Motosikletlerin Onarımı, H. Ulaştırma ve Depolama

Analiz edilen işletmelerin sektörel dağılımları ele alındığında imalat (\%41), finans ve sigorta (\%12), elektrik, gaz, buhar ve iklimlendirme üretimi ve dağıtımı (\%10), bilgi ve iletişim (\%10), toptan ve perakende ticaret, motorlu kara taşıtlarının ve motosikletlerin onarımı (\%9) ile ulaşım ve depolama (\%8) sektörleri ön plana çıkmaktadır. Projeler pazarlama ve sosyal girişimler bağlamında incelendiğinde imalat sektörü kurumsal hayırseverlik (\%41), işgücü gönüllülüğü $(\% 18)$ ve sosyal amaçlı teşvikler (\%18); finans ve sigorta sektörü kurumsal hayırseverlik (\%50) ile işgücü gönüllüllüğ̈ $(\% 20)$; bilgi ve iletişim sektörü kurumsal hayırseverlik (\%43) ile sosyal amaçlı teşvikler (\%15); toptan ve perakende sektörü kurumsal hayırseverlik (\%32), işgücü gönüllülüğü $(\% 25)$ ve kurumsal sosyal pazarlama (\%18); ulaştırma ve depolama sektörü kurumsal hayırseverlik (\%55), işgücü gönüllülügü $(\% 16)$ ve sosyal amaçlı teşvikler (\%16); elektrik, gaz, buhar ve iklimlendirme üretimi ve dağıtımı sektörü kurumsal hayırseverlik (\%40), kurumsal sosyal pazarlama (\%19) ve sosyal amaçlı teşvikler (\%17) girişimlerine yönelik faaliyetlere odaklandıkları görülmektedir.

${ }^{8}$ TÜİK’ten alınmıştır. 
Tablo 5: BM Sürdürülebilir Kalkınma Amaçlarına Göre KSS Faaliyetleri (Sektörel)

\begin{tabular}{ccccccccccccccccccc}
\hline $\begin{array}{c}\text { Sektör } \\
\text { Kodu }\end{array}$ & $\begin{array}{c}\text { İșletme } \\
\text { Sayısı }\end{array}$ & $\mathbf{1}$ & $\mathbf{2}$ & $\mathbf{3}$ & $\mathbf{4}$ & $\mathbf{5}$ & $\mathbf{6}$ & $\mathbf{7}$ & $\mathbf{8}$ & $\mathbf{9}$ & $\mathbf{1 0}$ & $\mathbf{1 1}$ & $\mathbf{1 2}$ & $\mathbf{1 3}$ & $\mathbf{1 4}$ & $\mathbf{1 5}$ & $\mathbf{1 6}$ & $\mathbf{1 7}$ \\
\hline $\mathbf{J}$ & $\mathbf{1 2}$ & 2 & 1 & 2 & 15 & 9 & 0 & 2 & 0 & 1 & 19 & 0 & 2 & 0 & 0 & 3 & 0 & 0 \\
\hline $\mathbf{P}$ & $\mathbf{1}$ & 0 & 0 & 1 & 4 & 0 & 0 & 0 & 0 & 0 & 8 & 0 & 0 & 0 & 0 & 1 & 0 & 0 \\
\hline $\mathbf{D}$ & $\mathbf{1 3}$ & 0 & 0 & 3 & 8 & 5 & 0 & 2 & 2 & 0 & 10 & 2 & 8 & 1 & 0 & 6 & 0 & 0 \\
\hline $\mathbf{K}$ & $\mathbf{1 5}$ & 0 & 1 & 8 & 27 & 4 & 0 & 0 & 3 & 1 & 31 & 7 & 2 & 2 & 1 & 8 & 0 & 2 \\
\hline $\mathbf{N}$ & $\mathbf{1}$ & 0 & 0 & 0 & 0 & 0 & 0 & 0 & 0 & 0 & 1 & 0 & 0 & 0 & 0 & 0 & 0 & 0 \\
\hline $\mathbf{C}$ & $\mathbf{5 2}$ & 5 & 5 & 25 & 31 & 23 & 1 & 0 & 12 & 4 & 57 & 12 & 9 & 6 & 3 & 30 & 0 & 2 \\
\hline $\mathbf{F}$ & $\mathbf{5}$ & 0 & 0 & 0 & 7 & 1 & 0 & 0 & 2 & 1 & 4 & 3 & 2 & 0 & 0 & 3 & 0 & 1 \\
\hline $\mathbf{R}$ & $\mathbf{1}$ & 0 & 0 & 2 & 0 & 0 & 0 & 0 & 1 & 0 & 0 & 0 & 0 & 0 & 0 & 0 & 0 & 0 \\
\hline $\mathbf{M}$ & $\mathbf{4}$ & 0 & 0 & 0 & 2 & 0 & 0 & 0 & 0 & 0 & 2 & 0 & 0 & 0 & 0 & 0 & 0 & 0 \\
\hline $\mathbf{E}$ & $\mathbf{1}$ & 0 & 0 & 0 & 0 & 0 & 0 & 1 & 0 & 0 & 0 & 0 & 1 & 1 & 0 & 0 & 0 & 0 \\
\hline $\mathbf{G}$ & $\mathbf{1 1}$ & 2 & 1 & 10 & 3 & 8 & 0 & 0 & 0 & 1 & 13 & 4 & 5 & 0 & 0 & 2 & 0 & 0 \\
\hline $\mathbf{H}$ & $\mathbf{1 0}$ & 3 & 3 & 2 & 8 & 1 & 0 & 2 & 1 & 0 & 14 & 4 & 1 & 1 & 0 & 7 & 0 & 1 \\
\hline & & & & & & & & & & & & & & & \\
\hline
\end{tabular}

Projeler BM Kalkınma Amaçları bağlamında incelendiğinde imalat sektörü eşitsizlerin azaltılması (\%25), nitelikli eğitim (\%14) ve karasal yaşam (\%13); finans ve sigorta sektörü eşitsizlerin azaltılması (\%32) ile nitelikli eğitim (\%60); bilgi ve iletişim sektörü eşitsizlerin azaltılması (\%34) ile nitelikli eğitim (\%27); toptan ve perakende sektörü eşitsizlerin azaltılması (\%27), sağlıklı ve kaliteli yaşam (\%20) ve toplumsal cinsiyet eşitliği (\%16); ulaştırma ve depolama sektörü eşitsizlerin azaltılması (\%29), nitelikli eğitim (\%17) ve karasal yaşam (\%15); elektrik, gaz, buhar ve iklimlendirme üretimi ve dağıtımı sektörü eşitsizlerin azaltılması (\%21), nitelikli eğitim (\%17) ve sorumlu üretim ve tüketim (\%17) amaçlarına yönelik faaliyetlere odaklandıkları görülmektedir.

Tablo 6: Pazarlama ve Kurumsal Sosyal Girişimlere Göre KSS Faaliyetleri (Menşei)

\begin{tabular}{|c|c|c|c|c|c|c|c|}
\hline \multirow[b]{2}{*}{ Menşei } & \multirow[b]{2}{*}{$\begin{array}{l}\text { Firma } \\
\text { Sayısı }\end{array}$} & \multicolumn{3}{|c|}{ Pazarlama Odaklı Girişimler } & \multicolumn{3}{|c|}{ Kurumsal Odaklı Girişimler } \\
\hline & & $\begin{array}{c}\text { Kurumsal } \\
\text { Sosyal } \\
\text { Pazarlama }\end{array}$ & $\begin{array}{c}\text { Sosyal } \\
\text { Amaçlı } \\
\text { Teşvikler }\end{array}$ & $\begin{array}{c}\text { Amaca } \\
\text { Yönelik } \\
\text { Pazarlama }\end{array}$ & $\begin{array}{c}\text { Kurumsal } \\
\text { Hayırseverlik }\end{array}$ & $\begin{array}{c}\text { İşyeri } \\
\text { Gönüllüğğü }\end{array}$ & $\begin{array}{l}\text { KSS Esashı İs } \\
\text { Uygulamaları }\end{array}$ \\
\hline Yerli & 87 & 65 & 71 & 15 & 198 & 77 & 26 \\
\hline Yabancı & 39 & 35 & 27 & 3 & 78 & 40 & 11 \\
\hline
\end{tabular}

Analiz edilen işletmelerin \%69'u yerli, \%31 ise yabancı kökenlidir. Projeler pazarlama ve sosyal girişimler bağlamında incelendiğinde yerli işletmelerin yoğunlaştığı girişimler sırasılyla kurumsal hayırseverlik (\%44), iş yeri gönüllülüğü (\%17), sosyal amaçlı teşvikler (\%16) ve kurumsal sosyal pazarlama (\%14) iken, yabancı kökenli işletmelerin ise kurumsal hayırseverlik (\%40), iş yeri gönüllülüğü (\%21), kurumsal sosyal pazarlama (\%18) ve sosyal amaçlı teşvikler (\%14) şeklindedir. 
Tablo 7: BM Sürdürülebilir Kalkınma Amaçlarına Göre KSS Faaliyetleri (Menşei)

\begin{tabular}{lcccccccccccccccccc}
\hline Menşei & $\begin{array}{c}\text { İşletme } \\
\text { Sayısı }\end{array}$ & $\mathbf{1}$ & $\mathbf{2}$ & $\mathbf{3}$ & $\mathbf{4}$ & $\mathbf{5}$ & $\mathbf{6}$ & $\mathbf{7}$ & $\mathbf{8}$ & $\mathbf{9}$ & $\mathbf{1 0}$ & $\mathbf{1 1}$ & $\mathbf{1 2}$ & $\mathbf{1 3}$ & $\mathbf{1 4}$ & $\mathbf{1 5}$ & $\mathbf{1 6}$ & $\mathbf{1 7}$ \\
& & & & & & & & & & & & & & & & & & \\
\hline Yerli & $\mathbf{8 7}$ & 11 & 7 & 29 & 68 & 33 & 1 & 5 & 15 & 5 & 113 & 20 & 22 & 7 & 3 & 43 & 0 & 5 \\
\hline Yabancı & $\mathbf{3 9}$ & 1 & 4 & 24 & 33 & 18 & 0 & 2 & 6 & 3 & 46 & 12 & 8 & 4 & 1 & 17 & 0 & 1 \\
\hline
\end{tabular}

Projeler BM Kalkınma Amaçları bağlamında incelendiğinde yerli işletmelerin yoğunlaştı̆̆ küresel amaçlar sırasıyla eşitsizliklerin azaltılması (\%29), nitelikli eğitim (\%18), karasal yaşam (\%11) ve sağlıklı ve kaliteli yaşam (\%8) iken, yabancı kökenli işletmelerin ise eşitsizliklerin azaltılması (\%26), nitelikli eğitim (\%18), sağlıklı ve kaliteli yaşam (\%13) ve karasal yaşam (\%9) şeklindedir.

\section{SONUC}

$\mathrm{Bu}$ çalışmada, Türkiye'de faaliyette bulunan işletmelerin KSS uygulamalarına odaklanılmıştır. KSS faaliyetleri pazarlama ve kurumsal sosyal girişimler ile BM sürdürülebilir kalkınma amaçları bağlamında ele alınmıştır. Elde edilen sonuçlara göre işletmelerin KSS uygulamaları daha çok kurumsal odaklı girişimler kapsamındadır. İşletmelerin özellikle kurumsal odaklı girişimlerden kurumsal hayırseverlik faaliyetlerine ağırlık verdikleri görülmektedir. Bunun yanında KSS esaslı iş uygulamaları ile amaca yönelik pazarlama kapsamına giren faaliyetler sınırlı sayıdadır. Küresel amaçlar bağlamında ise işletmelerin eşitsizliklerin azaltılmasına yönelik projelere ağırlık verdikleri görülmektedir. Bunu sırasıyla nitelikli eğitim, karasal yaşam, sağlıklı ve kaliteli yaşam ve toplumsal cinsiyet eşitliğine yönelik projeler takip etmektedir. Ancak barış, adalet ve güçlü kurumlar amacına yönelik bir proje saptanamamıştır. İşletmelerin nadiren odaklandıkları diğer küresel amaçlar ise temiz su ve sanitasyon, sudaki yaşam, erişilebilir ve temiz enerji ve sanayi, yenilikçilik ve altyapı şeklinde sıralanmaktadır. İşletmelerin gerçekleştirdikleri KSS projeleri gerek küresel kalkınma amaçları gerekse pazarlama ve sosyal girişimler açısından sektörel bazda birbiriyle benzeşmektedir. Aynı durum yerli ve yabancı menşeli işletmelerin odaklandıkları KSS projeleri için de geçerlidir.

KSS alanı çeşitli teoriler ve yaklaşımlar bağlamında ele alınmaktadır. Sürdürülebilir kalkınma yaklaşımı da bu teorilerden etik teoriler kapsamında değerlendirilmektedir (Gargia ve Mele, 2004). Bununla beraber sürdürülebilir kalkınma yaklaşımı ise ekonomik, çevresel ve sosyal olmak üzere üç boyutta ele alınmaktadır (Harris, 2000). Çalışmamızda analiz edilen KSS projelerinin büyük çoğunluğu sosyal projeler (\%69) kapsamındadır. Bunun yanında ekonomik $(\% 16)$ ve çevresel $(\% 15)$ boyutta yürütülen projeler ise yaklaşık olarak benzer orandadır. Buradan hareketle, işletmelerin yoğun olarak sosyal projelere ağırlık verdikleri görülmektedir. Sürdürülebilir kalkınma amaçlarına sağlıklı bir şekilde ulaşabilmek için ekonomik, çevresel ve sosyal boyutlara dengeli bir şekilde odaklanılması gerekmektedir. Bu sebeple işletmelerin KSS projelerinde dengeye ulaşabilme adına ekonomik ve çevresel projelere ağırlık vermeleri önem arz etmektedir.

Türkiye'de faaliyet gösteren işletmelerin KSS raporlarının ele alındığı çalışmalarda, Pusak işletmelerin raporlarında (2014) çevre, paydaşlar, eğitim, sağlik ve güvenlik; Soysal (2018) çevre, paydaşlar, eğitim, kültür ve sanat; Aytar (2019) da çevre ve eğitim konularına odaklandıklarını belirtmektedir. Süklüm ve Hiçyorulmaz (2019) işletmelerin çevreyle ilgili konularda duyarlı olduklarını ifade etmektedir. Çalışmamızın sonuçları özellikle eğitim, çevre ve paydaşlara yönelik projelerde diğer çalışmalarla benzeşmektedir. 
Çeşitli ülkelerde, çeşitli sektörlerden işletmelerin sürdürülebilir kalkınma amaçları bağlamında ele alındığı çalışmalara göre, Gana'da faaliyet gösteren maden ve telekomünikasyon sektörlerinin yoksulluğa son, sağliklı ve kaliteli yaşam, nitelikli eğitim ve sanayi, yenilikçilik ve altyapı (Kumi vd., 2020), Hindistan'daki işletmelerin nitelikli eğitim, temiz su ve sanitasyon, erişilebilir ve temiz enerji, eşitsizliklerin azaltılması (Jha ve Rangarajan, 2020), Endonezya'daki işletmelerin insana yakışır iş ve ekonomik büyüme, barış, adalet ve güçlü kurumlar, amaçlar için ortaklıklar (Ridho vd., 2018), Avrupa'nın önde gelen beş bankasının nitelikli eğitim, insana yakışır iş ve ekonomik büyüme, barış adalet ve güçlü kurumlar (Avrampou vd., 2019) amaçlarına odaklandıkları görülmektedir. Bu noktada diğer ülkelerde de öncelenen amaçlarda nitelikli eğitim, sağlıklı ve kaliteli yaşam ve eşitsizliklerin azaltılması amaçları Türkiye'de de öncelenmektedir. Bunun yanında barış, adalet ve güçlü kurumlar, insana yakışır iş ve ekonomik büyüme, temiz su ve sanitasyon ile erişilebilir ve temiz enerji diğer ülkelerin aksine Türkiye'de geri planda kalmaktadır.

Pazarlama biliminde temelde iki farklı yaklaşım söz konusudur. $\mathrm{Bu}$ yaklaşımlar kapitalizmin iki farklı yansıması olarak Anglo-Sakson (pazarlama yönetimi) ve Alp-Germen (ilişkisel pazarlama) yaklaşımlarıdır. Pazarlama yönetiminde değişime, ilişkisel pazarlamada ise ilişkilere odaklanılmaktadır (Erdoğan ve Tiltay, 2018: 32). Ancak, Batılı yaklaşımların Batılı olmayan bağlamları açıklamasında çeşitli sorunlar ortaya çıkmaktadır. Bu noktada, Türkiye'deki pazarlama uygulamalarını kendi bağlamında açıklayabilecek erdem odaklı Anadolu Yaklaşımı önerilmektedir. $\mathrm{Bu}$ yaklaşım, Anadolu bağlamını açıklamada daha iyi bir teorik yaklaşım sağlayacaktır (Erdoğan ve İşlek, 2018:186). Anadolu yaklaşımının temelleri Hisbe ve Ahi teşkilatlarına dayanmaktadır. Bu teşkilatların üzerindeki ilk etki kaynağı ise Medine pazarlarıdır. $\mathrm{Bu}$ teşkilatların takip ettikleri temel ilke "iyiliği emret, kötülükten sakındır" ilkesidir. Bu ilke, pazar ve pazar ilişkilerini anlamanın İslami yolunu ifade etmektedir. Buradan hareketle, İslam ahlakına ve geleneklerine uygun iş yapma kaygısı, Anadolu Yaklaşımının ana öğesidir (Erdoğan vd. 2020: 95). Anadolu Yaklaşımı sadece dünyevi kazancı değil, erdemi merkeze alarak manevi ve uhrevi kazanımları da amaçlayan bir pazar pratiğinin günümüzde de mümkün olduğunu savunmaktadır (Erdoğan ve İşlek, 2018: 199). Bu yaklaşımdan hareketle Anadolu pazar sistemini ele alan İşlek (2019), pratikte ilişkisel ve işlemsel ilişkilerin bir arada bulunduğunu tespit etmiştir. Suher (2010) de Türk ve küresel işletmelerin KSS yaklaşım ve uygulamalarının benzerlik gösterdiğini belirtmektedir. Çalışmamızda yerel ve yabancı menşeli işletmelerin KSS faaliyetlerinin paralellik göstermesi İşlek (2019) ve Suher'in (2010) çalışmalarıyla benzeşmektedir.

İşletmelerin ayni ve nakdi yardımda bulundukları hayırseverlik faaliyetlerine ağırlık verdiklerini daha önce belirtmiştik. Bu noktada tek seferlik katkıdan ziyade özellikle sosyal sorumluluk esaslı iş uygulamaların ve davranış değişikliği oluşturmayı hedefleyen kurumsal sosyal pazarlama faaliyetlerinin artırılmasına yönelik projelerin öncelenmesi daha sürdürülebilir görünmektedir. Özellikle bireyin hayatının geri kalanı üzerinde önemli yansımaları olan gelişim çağındaki (Mannheim, 1952) bireylere yönelik davranış değişikliği meydana getirebilecek projelerin etkisi daha uzun ve kalıcı olacaktır. Bu yaklaşımı küresel sürdürülebilir kalkınma amaçları kapsamında da sürdürmek mümkündür. Son dönemlerde etkisi daha da belirginleşen küresel ısınma ve buna bağlı olarak iklim değişikliği dünyamızı hiç olmadığı kadar tehdit etmektedir. Türkiye'nin de kuraklık ile anılmaya başlaması (ntv.com.tr) özellikle iklim eylemi, erişilebilir ve temiz enerji, temiz su ve sanitasyon, sürdürülebilir şehirler ve topluluklar ile sorumlu üretim ve tüketim amaçlarına yönelik faaliyetlerin daha fazla gündeme alınmasını zorunlu kılmaktadır. Ancak, belirtilen bu amaçlara yönelik KSS faaliyetlerinin oranının çok düşük kalması dikkate değerdir. Bu noktada KSS faaliyetlerinin tüm alanlara yayılması önem arz etmektedir.

Çalışmada ele alınan KSS raporları işletmelerin web sayfalarında kamuoyuyla paylaştıkları raporlarla sınırlıdır. Ayrıca belirlenen işletmeler Türkiye'de faaliyette bulunan ve 
KSS uygulamalarına sahip bütün işletmeleri kapsamamaktadır. $\mathrm{Bu}$ sebeple ileriye yönelik çalışmalarda, Türkiye'deki KSS faaliyetleri yürüten tüm işletmeleri kapsayan çalışmaların yapılması önerilmektedir. Ayrıca, özellikle son dönemlerde önemi daha da derinden hissedilen su ve su kaynaklarının korunması ve su tüketim bilincinin önemine yönelik projelerin neden ihmal edildiği önem arz eden diğer bir araştırma konusudur.

\section{Araştırma ve Yayın Etiği Beyanı}

$\mathrm{Bu}$ çalışma bilimsel araştırma ve yayın etiği kurallarına uygun olarak hazırlanmıştır.

\section{Yazarların Makaleye Katkı Oranları}

Yazarların makaleye katkıları eşittir.

\section{Çıkar Beyanı}

Yazarlar açısından ya da üçüncü taraflar açısından çalışmadan kaynaklı çıkar çatışması bulunmamaktadır. 


\section{KAYNAKÇA}

Ahi, P., \& Searcy, C. (2013). A comparative literature analysis of definitions for green and sustainable supply chain management. Journal of Cleaner Production, 52, 329-341. https://doi.org/10.1016/j.jclepro.2013.02.018

Aktan, C. C. ve Börü, D. (2007). Kurumsal sosyal sorumluluk. Coşkun Can Aktan (Ed.), Kurumsal Sosyal Sorumluluk: Issletmeler ve sosyal sorumluluk (s. 11-36) İGİAD Yayınları

Arli, D. I., \& Lasmono, H. K. (2010). Consumers' perception of corporate social responsibility in a developing country. International Journal of Consumer Studies, 34(1), 46-51. https://doi.org/10.1111/j.1470-6431.2009.00824.x

Avrampou, A., Skouloudis, A., Iliopoulos, G., \& Khan, N. (2019). Advancing the sustainable development goals: Evidence from leading European banks. Sustainable Development, 27(4), 743-757. https://doi.org/10.1002/sd.1938

Aytar, O. (0219). BİST sürdürülebilirlik endeksinde yer alan şirketlerin kurumsal sosyal sorumluluk faaliyetleri üzerine bir içerik analizi. OPUS Uluslararası Toplum Araştırmaları Dergisi, 12, 1-1. https://doi.org/10.26466/opus.583811

Brønn, P. S., \& Vrioni, A. B. (2001). Corporate social responsibility and cause-related marketing: An overview. International Journal of Advertising, 20(2), 207-222. https://doi.org/10.1080/02650487.2001.11104887

Carroll, A. B. (1991). The pyramid of corporate social responsibility: Toward the moral management of organizational stakeholders. Business Horizons, 34(4), 39-48. https://doi.org/10.1016/0007-6813(91)90005-G

Cone Communications (2011), Cone/Echo global cr opportunity study. https://www.conecomm.com/2011-conecommunicationsecho-global-cr-opportunity-study-pdf, Retrieved on December 09, 2020)

Dahlsrud, A. (2008). How corporate social responsibility is defined: an analysis of 37 definitions. Corporate Social Responsibility and Environmental Management, 15(1), 1-13. https://doi.org/10.1002/csr.132

Demirel, B. (2018). Türkiye'nin ilk 200 imalat firmasının periyodik olarak yayınlanan kurumsal sosyal sorumluluk raporlarının içerik analizi. Yayımlanmamış yüksek lisans tezi, Manisa Celal Bayar Üniversitesi, Sosyal Bilimler Enstitüsü, İşletme Anabilim Dalı.

Erdoğan, B.Z. ve İşlek, M. S. (2018). Pazarlamaya erdem yönlü yaklaşım. B.Z. Erdoğan (Ed.), Bilim olarak pazarlama, (ss. 185-206). İstanbul: Beta Yayınları.

Erdoğan, B.Z. ve Tiltay, M. A. (2018). Pazarlama biliminin evrimi. B.Z. Erdoğan (Ed.), Bilim olarak pazarlama, (ss. 21-44). İstanbul: Beta Yayınları.

Erdoğan, B.Z., Torlak Ö., Yılmaz C., Özmen M. ve İşlek M.S. (2020). Alternative marketing ethics within the context of the madinah markets and akhi organizations: The anatolian approach. Iss Ahlakı Dergisi, 13 (2), ss. 82-102. DOI: 1012711/tjbe.2020.13.2.0162

Esen, E. (2013), "The influence of corporate social responsibility (csr) activities on building corporate reputation", Alejandra Gonzalez-perez, M. and Leonard, L. (Ed.) International Business, Sustainability and Corporate Social Responsibility (Advances in Sustainability and Environmental Justice, Vol. 11), Emerald Group Publishing Limited, Bingley, pp. 133-150. https://doi.org/10.1108/S2051-5030(2013)0000011010

Garriga, E., \& Melé, D. (2004). Corporate social responsibility theories: Mapping the territory. Journal of Business Ethics, 53(1), 51-71.

Gautier, A., \& Pache, A. C. (2015). Research on corporate philanthropy: A review and assessment. Journal of Business Ethics, 126(3), 343-369. https://doi.org/10.1007/s10551-013-1969-7

Harris, J. M. (2000). Basic principles of sustainable development, Dimensions of sustainable development, 21-41.

Holcomb, J. L., Upchurch, R. S., \& Okumus, F. (2007). Corporate social responsibility: What are top hotel companies reporting? International Journal of Contemporary Hospitality Management. https://doi.org/10.1108/09596110710775129

Hsieh, H. F., \& Shannon, S. E. (2005). Three approaches to qualitative content analysis. Qualitative Health Research, 15(9), 1277-1288. https://doi.org/10.1177/1049732305276687

Idowu, S. O., \& Towler, B. A. (2004). A comparative study of the contents of corporate social responsibility reports of UK companies, Management of Environmental Quality, Vol. 15 No. 4, pp. 420-437. https://doi.org/10.1108/14777830410540153

İçigen, E., Çevik, B. ve Doğan, O. (2016). Türkiye'de faaliyet gösteren uluslararası konaklama işletmelerinin sosyal sorumluluk uygulamalarının incelenmesi. Mediterranean Journal of Humanities, 6(2), 299-310. Doi: 10.13114/MJH.2016.299 
İşlek M.S. (2019). Anadolu pazar sisteminde alıcı ve satıcı ilişskilerinin analizi. Yayımlanmamış doktora tezi, Anadolu Üniversitesi, SBE, Eskişehir.

Jackson, G., \& Apostolakou, A. (2010). Corporate social responsibility in Western Europe: An institutional mirror or substitute? Journal of Business Ethics, 94(3), 371-394. https://doi.org/10.1007/s10551-009-0269-8

Jha, M. K., \& Rangarajan, K. (2020). The approach of Indian corporates towards sustainable development: An exploration using sustainable development goals based model. Sustainable Development, 28(5), 1019-1032. https://doi.org/10.1002/sd.2053

Kim, M., Yin, X., \& Lee, G. (2020). The effect of CSR on corporate image, customer citizenship behaviors, and customers' long-term relationship orientation. International Journal of Hospitality Management, 88, 102520. https://doi.org/10.1016/j.ijhm.2020.102520

Kotler, P., \& Levy, S. J. (1969). Broadening the concept of marketing. Journal of Marketing, 33(1), 10-15. https://doi.org/10.2307/1248740

Kotler, P., \& Zaltman, G. (1971). Social marketing: An approach to planned social change. Journal of Marketing, 35(3), 3-12. https://doi.org/10.2307/1249783

Kotler, P., Hessekiel, D., \& Lee, N. (2012). Goodworks!: Marketing and corporate initiatives that build a better world... and the bottom line. John Wiley\&Sons.

Krippendorff, K. (2004). Content analysis: An introduction to its methodology. Sage publications.

Kumi, E., Yeboah, T., \& Kumi, Y. A. (2020). Private sector participation in advancing the sustainable development goals (SDGs) in Ghana: Experiences from the mining and telecommunications sectors. The Extractive Industries and Society, 7(1), 181-190. https://doi.org/10.1016/j.exis.2019.12.008

Küresel Amaçlar, https://www.kureselamaclar.org, Erişim tarihi: 09.12.2020

Lee, K. H., \& Shin, D. (2010). Consumers' responses to CSR activities: The linkage between increased awareness and purchase intention. Public Relations Review, 36(2), 193-195. https://doi.org/10.1016/j.pubrev.2009.10.014

Luck, D. J. (1969). Marketing notes and communications: Broadening the concept of marketing-Too far. Journal of Marketing, 33(3), 53-55. https://doi.org/10.1177/002224296903300310

Macit, N. (2020). BIST şirketlerinin kurumsal sosyal sorumluluk faaliyetleri: BIST 30, BIST 50, BIST 100 endeksleri üzerine karşılaştırmalı bir içerik analizi. Yayımlanmamış yüksek lisans tezi. Karamanoğlu Mehmetbey Üniversitesi, Sosyal Bilimler Enstitüsü, Karaman.

Maç, S. D., Turan, Ş.A., Okutan, S., ve Metin, O. (2020). The transition from philanthropy to corporate social responsibility (CSR) in developing countries: An analysis of award-winning CSR projects in Turkey. Işs Ahlakl Dergisi, 13 (2), ss. 146-170. DOI: 10.12711/tjbe.2020.13.2.0168

Madran C. ve Tanyeri M. (2020). Sürdürülebilir kalkınma amaçları ile kurumsal dönüşüm. Akademisyen Kitabevi, Ankara.

Maignan, I., \& Ferrell, O. C. (2004). Corporate social responsibility and marketing: An integrative framework. Journal of the Academy of Marketing Science, 32(1), 3-19. https://doi.org/10.1177/0092070303258971

Malik, M. (2015). Value-enhancing capabilities of CSR: A brief review of contemporary literature. Journal of Business Ethics, 127(2), 419-438. https://doi.org/10.1007/s10551-014-2051-9

Mannheim, K. (1952). The problem of generations. In Essays on the sociology of knowledge, pp. 276-320. NY: Oxford Univ. Press.

Martínez, P., \& Del Bosque, I. R. (2013). CSR and customer loyalty: The roles of trust, customer identification with the company and satisfaction. International Journal of Hospitality Management, 35, 89-99. https://doi.org/10.1016/j.ijhm.2013.05.009

Mensah Jç (2019) Sustainable development: Meaning, history,principles, pillars, and implications for human action: Literature review, Cogent Social Sciences, 5:1, 1653531, https://doi.org/10.1080/23311886.2019.1653531

Mucan, B., Kayabaşı, A., \& Madran, C. (2016). Yöneticilerde sürdürülebilirlik algısı ve firma uygulamalarına yönelik değerlendirme. Ekonomik ve Sosyal Araştırmalar Dergisi, $12(2), \quad 57-72$. https://dergipark.org.tr/tr/pub/esad/issue/38969/456207

NTV, (2021, 19 Ocak), NASA'dan Türkiye'ye kuraklık uyarlsı, https://www.ntv.com.tr/galeri/teknoloji/nasadanturkiyeye-kuraklik-uyarisi,fHPalz0-JkuH_YsKbA2Fjw Erişim tarihi: 21.01.2021 
Okoye, A. (2009). Theorising corporate social responsibility as an essentially contested concept: Is a definition necessary? Journal of Business Ethics, 89(4), 613-627. https://doi.org/10.1007/s10551-008-0021-9

Pusak, S. (2014). Türkiye'de kurumsal sosyal sorumluluk üzerine bir araştırma; şirketlerin periyodik yayınlanan kurumsal sosyal sorumluluk raporlarının içerik analizi. Yayımlanmamış yüksek lisans tezi. Çağ Üniversitesi, Sosyal Bilimler Enstitüsü, İşletme Yönetimi Anabilim Dalı.

Ridho, T.K., Vinichenko, M., \& Makushkin, S. (2018). Participation of companies in emerging markets to the Sustainable Development Goals (SDGs). Proceedings of the 34th International Scientific Conference on Economic and Social Development - XVIII International Social Congress (ISC-2018) (pp. 741-752). Moscow.

Rodell, J. B. (2013). Finding meaning through volunteering: Why do employees volunteer and what does it mean for their jobs? Academy of Management Journal, 56(5), 1274-1294. https://doi.org/10.5465/amj.2012.0611

Sert, N. Y. (2012). Türkiye'de özel sektörün kurumsal sosyal sorumluk anlayışına ilişkin yarar algısı: Kurumsal sosyal sorumluluk faaliyetlerinin duyurulmasında web sitelerinin kullanılması. AJIT-e: Online Academic Journal of Information Technology, 3(9). DOI: 10.5824/1309-1581.2012.4.003.x

Soysal, B. (2018), kurumsal sosyal sorumluluk raporlaması ve Türk şirketleri üzerine bir içerik analizi, ANASAY, (6), 11-38. https://doi.org/10.33404/anasay.488457

Steurer, R., Langer, M. E., Konrad, A., \& Martinuzzi, A. (2005). Corporations, stakeholders and sustainable development I: A theoretical exploration of business-society relations. Journal of Business Ethics, 61(3), 263-281. https://doi.org/10.1007/s10551-005-7054-0

Suher, İ. (2010). Zirvedeki Türk işletmelerinin kurumsal sosyal sorumluluk iletişimi: Web sitelerine yönelik bir inceleme. Selçuk Illetişim, 6(2), 33-48. https://dergipark.org.tr/tr/pub/josc/issue/19020/200632

Süklüm, N. ve Hiçyorulmaz, E. (2019). BİST sürdürülebilirlik endeksindeki işletmelerin sosyal sorumluluk ve çevre muhasebesi ilişkisi açısından incelenmesi: Bir içerik analizi. Business \& Management Studies: An International Journal, 7(4), 1806- 1824. https://doi.org/10.15295/bmij.v7i4.1152

Sürdürülebilir Kalkınma Amaçları, https://www.tr.undp.org/content/turkey/tr/home/sustainable-developmentgoals.html, Erişim tarihi: 09.12.2020

Tate, W. L., Ellram, L. M., \& Kirchoff, J. F. (2010). Corporate social responsibility reports: A thematic analysis related to supply chain management. Journal of Supply Chain Management, 46(1), 19-44. https://doi.org/10.1111/j.1745-493X.2009.03184.X

Van Beurden, P., \& Gössling, T. (2008). The worth of values-a literature review on the relation between corporate social and financial performance. Journal of Business Ethics, 82(2), 407. https://doi.org/10.1007/s10551-008-9894-X

VonSchnurbein, G., Seele, P. \& Lock, I. (2016), "Exclusive corporate philanthropy: rethinking the nexus of CSR and corporate philanthropy", Social Responsibility Journal, Vol. 12 No. 2, pp. https://doi.org/10.1108/SRJ-10-2014-0149

World Commission on Environment and Development (1987). Our common future. Oxford University Press, Oxford. 


\section{Extended Summary}

\section{Corporate Social Responsibility Practices in The Context of Sustainable Development Goals: Current Situation and Trends in Turkey}

This study aims to elucidate the current situations and trends regarding CSR practices of award-winning businesses operating in Turkey. The CSR activities analyzed were classified in the context of marketing and corporate social initiatives (Kotler et al., 2012) and the United Nations Sustainable Development Goals (SDGs) index.

Marketing academics' interest in corporate social responsibility began in the 1960s and 1970s. At that time, the focus of researchers was on social tasks related to the marketing function rather than the general social role of the enterprises (Maignan and Ferrell, 2004: 4). During this period, Kotler and Levy (1969) stated that marketing is a social activity that goes beyond mere sales activities and permeates everywhere. With the emergence of social marketing (Kotler \& Zaltman, 1971), the contribution of marketing to the social sphere has improved.

Businesses undertake various initiatives within the scope of CSR activities. These initiatives are basically classified under two headings: (1) Marketing-driven initiatives, (2) Corporate-driven initiatives. Marketing and corporate social initiatives is defined as "major activities undertaken by a corporation to support social causes, strengthen its business, and fulfill commitments to corporate social responsibility" (Kotler et. al., 2012: 6).

The Sustainable Development Goals first emerged at the United Nations Sustainable Development Conference held in Rio de Janeiro in 2012. Its purpose is to set universal goals that address environmental, political and economic problems. Global Sustainable Development Goals is a universal call to action, guiding UNDP (United Nations Development Program) policy and funding until 2030, which entered into force in January 2016 for the peace and prosperity of all humanity, the eradication of poverty, and the protection of the planet.

This study is applied and exploratory research. Document analysis was applied in the data collection process. CSR projects published on the web pages of businesses operating in Turkey were examined. Criterion sampling, one of the purposeful sampling techniques, was applied in the study. Following criteria were used in the selection of businesses whose CSR reports were examined.

- 57 businesses that were awarded by the Corporate Social Responsibility Association of Turkey (CSR Turkey) between 2009-2019,

- 32 businesses that were awarded by Turkish Confederation of Employer Association between 2014-2018,

- 45 businesses that were awarded by Sustainability Academy between 2014-2019,

- 47 businesses that were awarded by BIST Sustainability Index for the period of 2018-2020. 520 CSR activities carried out by 126 businesses were analyzed. Qualitative and quantitative content analysis was performed (Krippendorf, 2004; Hsieh and Shannon, 2005). The reports examined were subjected to content analysis by each researcher. A classification was made under predetermined subject titles. In these classifications, a dual classification approach has been adopted by the researchers:

- Marketing and corporate social initiatives (Kotler et.al., 2012).

- The United Nations Sustainable Development Goals (SDGs) index.

Approximately $70 \%$ of the 520 CSR projects analyzed in the context of marketing and corporate social initiatives are within the scope of corporate-driven initiatives and $30 \%$ are within the scope of marketing-driven initiatives. It is found that the projects within the 
scope of corporate philanthropy are more intense in corporate-driven projects. When the analyzed social responsibility projects are ranked in order of intensity, the results are: corporate philanthropy (43\%), workforce volunteering (18\%), cause promotion (15\%), corporate social marketing (15\%), socially responsible business practices $(6 \%)$ and causerelated marketing (3\%).

When the distribution of the social responsibility projects of businesses according to the Sustainable Development Goals is examined, the intensity is on projects focused on reduced inequalities (28\%), quality education (18\%), life on land (11\%), good health and well-being (10\%) and gender equality (9\%). However, the distribution of projects for other goals is sustainable cities and communities $(5 \%)$, responsible consumption and production $(5 \%)$, decent work and economic growth (4\%), zero hunger (2\%), no poverty (2\%), climate action (2\%), industry, innovation and infrastructure (1\%), affordable and clean energy (1\%) and others $(2 \%)$. In the social responsibility reports examined in the context of this study, the social responsibility project, whose primary goal is peace, justice and strong institutions, could not be determined.

Considering the sectoral distribution of the analyzed businesses, the manufacturing (41\%) sector comes to the fore. The manufacturing sector gives priority to corporate philanthropy activities in the scope of marketing and corporate social initiatives (\%41) and reduced inequalities (\%25) in the scope of the sustainable development goals.

$69 \%$ of the analyzed businesses are domestic in origin. Both domestic and foreigner businesses focus mainly on corporate philanthropy (\%44, \%40, respectively) within the context of marketing and corporate social initiatives and reduced inequalities (\%29, \%26, respectively) within the context of the sustainable development goals.

Businesses concentrate on philanthropic activities to which they provide in-kind and incash aid. At this point, it seems more sustainable to prioritize projects aimed at increasing socially responsible business practices and corporate social marketing activities aimed at creating behavioral change rather than a one-off contribution. Especially, the effects of projects that can bring about behavioral change for individuals in the formative years (Mannheim, 1952), which have important reflections on the rest of the life of the individual, will be longer and permanent. It is possible to maintain this approach within the scope of global sustainable development goals. Global warming and climate change, whose effect has become more evident in recent years, threaten the world more than ever. Turkey began to be referred to as a country that has implications of drought (ntv.com.tr). Particularly, activities regarding climate action, affordable and clean energy, clean water and sanitation, sustainable cities and communities, and responsible production and consumption purposes must be placed more on the agenda. However, it is noteworthy that the rate of CSR activities towards these stated purposes remains insufficient. At this point, it is important to spread CSR activities to all global goals. 
Optimum Journal of Economics and Management Sciences, Vo1. 8, No. 2- https://dergipark.org.tr/tr/pub/optimum Tiltay, $\ddot{O}_{z}$ and Tepe - Corporate Social Responsibility Practices in the Context of Sustainable Development Goals: Current Situation and Trends in Turkey 